\title{
PENGARUH GAYA MENGAJAR RESIPROKAL TERHADAP HASIL MENENDANG BOLA DALAM PERMAINAN SEPAK BOLA PADA SISWA PUTRA KELAS VII SMPN 1 GERUNG LOMBOK BARAT
}

\author{
Sylvana Yaka Saputra ${ }^{1}$, Ni Ketut Alit Suarti ${ }^{2}$, Isnaini ${ }^{3}$ \\ email: sylvanayakasaputra1990@gmail.com ${ }^{1}$, niketutalitsuarti@ikipmataram.ac.id ${ }^{2}$, isnaini@gmail.com ${ }^{3}$ \\ Program Studi Pendidikan Jasmani Kesehatan dan Rekreasi, Universitas Nahdlatul Ulama NTB ${ }^{1}$, \\ Program Studi Pendidikan Jasmani Kesehatan dan Rekreasi, IKIP Mataram ${ }^{2,3}$
}

\begin{abstract}
Abstrak
Penelitian ini bertujuan untuk mengetahui pengaruh gaya mengajar resiprokal terhadap hasil menendang bola dalam permainan sepak bola pada siswa putra kelas VII SMPN 1 Gerung Lombok Barat. Penelitian ini mengguanakan metode eksperimen dengan bentuk pre eksperimental design yaitu One grup pretest-posttest design. Populasi dalam penelitian ini adalah siswa putra kelas VII SMPN 1 Gerung Lombok Barat yang berjumlah 101 orang dan sampel dalam penelitian ini adalah siswa putra kelas VII SMPN 1 Gerung Lombok Barat yang berjumlah 31 orang yang diambil dengan teknik porposional random sampling. Teknik pengumpulan data dengan menggunakan tes perbuatan untuk mengetahui hasil menendang bola dalam permainan sepak bola. Analisis data dengan menggunakan uji t yaitu dengan rumus t test dan diperoleh $t_{\text {hitung }}>t_{\text {tabel. }}(5,648>2042)$. Dengan demikian dapat disimpulkan bahwa ada pengaruh gaya mengajar resiprokal terhadap hasil menendang bola dalam permainan sepak bola pada siswa putra kelas VII SMPN 1 Gerung Lombok Barat.
\end{abstract}

Kata kunci: Gaya Mengajar Resiprokal, Hasil menendang bola.

\begin{abstract}
This study aims to determine the effect of reciprocal teaching styles on the results of kicking the ball in the game of soccer in seventh grade male students of Gerung 1 Junior High School, West Lombok. This study used the experimental method with a pre-experimental design, one group pretest-posttest design. The population in this study were seventh grade male students of Gerung 1Junior High School West Lombok 1, and the sample in this study were seventh grade male students of Gerung 1 junior high school West Lombok 1, totaling 31 people taken by proportional random sampling technique. The technique of collecting data is by using an action test to find out the results of kicking a ball in a soccer game. Data analysis using the $t$ test, namely the formula $t$ test and obtained tcount $>t$ table. $(5,648>2042)$. Thus it can be concluded that there is an influence of reciprocal teaching style on the results of kicking the ball in the game of football in seventh grade male students of Gerung 1 Junior High School, West Lombok
\end{abstract} Keywords: Reciprocal Teaching Style, the result of kicking the ball

\section{A. Pendahuluan}

Permainan sepak bola merupakan cabang olahraga terpopuler didunia. Hal ini dilihat dari berjuta-juta orang lebih menyaksikan piala dunia atau pertandingan internasiaonal lainnya, dari pada menyaksikan pertandingan olahraga yang lain. Dalam masyarakat global yang dipisahkan 
oleh perbedaan fisik dan ideologi, ketenaran sepak bola tidak dilihat dari unsur jenis kelamin dan kebudayaan atau batasan etnik. Gerakan pemain yang terkontrol mengekspresikan individualitas dalam permainan beregu, kecepatan kekuatan, stamina, ketrampilan dan pengetahuan mengenai teknik, teknik semacamnya merupakan aspek yang penting dari penampilan berbagai tantangan yang dihadapi oleh pemain, menjadi daya tarik utama dari permainan ini. Di Indonesia mulai dari yang anak-anak hingga orang dewasa sangat menggemari permainan sepak bola buktinya permainan sepak bola di negara Indonesia sudah merakyat. Teknik dasar yang ada dalam permainan sepak bola secara garis besar dapat dibagi menjadi dua yaitu teknik tanpa bola (teknik badan) dan teknik dengan bola. "Teknik dengan badan yaitu cara pemain menguasai gerak tubuhnya dalam permainan yang menyangkut cara berlari, melompat, dan gerak tipu badan. Sedangkan teknik dengan bola yaitu gerakan-gerakan dengan bola, antara lain menendang, menahan, menggiring dan menyundul" (Muhajir, 2007: 3). Pembelajaran menendang bola dalam permainan sepak bola pada umumnya terhambat oleh ketidakberanian siswa dalam melakukan gerakan. Ketegangan siswa terhadap gurunya menjadi penghalang siswa untuk berani mencoba gerakan yang sebenarnya ingin dilakukan tetapi melalui gaya mengajar resiprokal siswa akan lebih berani mencoba melakukan apa yang dilakukannya. Gaya mengajar resiprokal memberi kesempatan kepada siswa untuk turut serta menilai dan mengoreksi satu sama lain dan merangsang nalar berfikir siswa dalam memecahkan masalah yang muncul dalam permainan sepak bola hal ini akan berpengaruh pada hasil belajar siswanya khususnya teknik menendang bola dalam permainan sepak bola.

\section{B. Metode}

Penelitian ini menggunakan metode penelitian eksperimen. Penelitian eksperimen adalah merupakan penelitian yang sistematis, logis, dan teliti di dalam melakukan kontrol terhadap kondisi. Dalam penelitian eksperimen memanipulasikan suatu stimul, treatment atau kondisikondisi ekspremental, kemudian mengobservasi pengaruh yang diakibatkan oleh adanya perlakuan atau manipulasi tersebut" (Riyanto, 2011:29). Sehubungan dengan uraian di atas, maka peneliti menggunakan metode eksperimen dengan bentuk pre eksperimental design yaitu One-Grup Pretest-Posttest Design, karena harus mengumpulkan data hasil dari pengukuran hasil menendang bola dalam permainan sepak bola sebelum diterapkan gaya mengajar resiprokal dan hasil menendang bola sesudah diterapkan gaya mengajar resiprokal. Sesuai dengan metode penelitian ini yaitu metode eksperimen, maka pola rancangan yang digunakan dalam pelaksanaan penelitian adalah “One-Group Pretest-Posttest Design” (Sugiyono, 2011: 111). Adapun bentuk rancangan yang dimaksud adalah seperti yang tertera pada gambar di bawah ini:

\section{$\mathrm{O}_{1} \mathrm{X} \mathrm{O}_{2}$}

Keterangan gambar:

$\mathrm{O}_{1}=$ Hasil menendang bola sebelum diterapkan gaya mengajar resiprokal (pre-test).

$\mathrm{X}=$ Gaya mengajar resiprokal (treatment).

$\mathrm{O}_{2}=$ Hasil menendang bola setelah diterapkan gaya mengajar resiprokal (post-test). 
Untuk memperoleh data yang diperlukan dalam penelitian, maka peneliti menggunakan teknik pengumpulan data yaitu test perbuata. Test adalah serentetan atau latihan yang digunakan untuk mengukur ketrampilan, pengetahuan, sikap, inteligensi, atau bakat yang dimiliki oleh individu atau kelompok" (Riyanto, 2011: 84). Sedangkan ahli lain berpendapat bahwa "test adalah merupakan alat ukur prosedur yang digunakan untuk mengetahui atau mengukur sesuatu dalam suasana, dengan cara dan aturan-aturan yang sudah yang sudah ditentukan" (Arikunto, 2010: 53). Berdasarkan beberapa pendapat di atas, maka dapat disimpulkan bahwa metode tes adalah merupakan alat untuk mengetahui atau mengukur keterampilan, pengetahuan, sikap, intelegensi, atau bakat yang dimiliki oleh individu atau kelompok dengan cara dan aturan-aturan yang sudah ditentukan. Dalam penelitian ini menggunakan metode tes perbuatan sebagai metode pokok untuk mengukur hasil menendang sebelum dan setelah peneliti menggunakan gaya mengajar resiprokal pada siswa putra kelas VII SMPN 1 Gerung Lombok Barat. Analisis data yang digunakan dalam penelitian ini adalah analisa statistik dengan menggunakan uji t ( $t$-test) ini berguna untuk menguji kebenaran hipotesis dan menjawab permasalahan yang diajukan dalam penelitian

Adapun rumus yang dimaksud adalah:

$$
t=\frac{M_{I}-M_{I I}}{\sqrt{\frac{\sum d^{2}}{N(N-1)}}}
$$

\section{Keterangan:}

$\mathrm{M}_{\mathrm{I}}=$ angka rata-rata hasil menendang bola setelah diterapkan gaya mengajar resiprokal.

$\mathrm{M}_{\mathrm{II}}=$ angka rata-rata hasil menendang bola sebelum diterapkan gaya mengajar resiprokal.

$\mathrm{d}^{2}=\mathrm{D}-\mathrm{Md}$ dan $\mathrm{Md}=\frac{\sum D}{N}$ Sedangkan $\mathrm{D}=\mathrm{X}_{1}-\mathrm{X}_{2}$

$\mathrm{N}=$ jumlah sampel

\section{Hasil dan Pembahasan}

Data-data yang berhubungan dengan pelaksanaan penelitian ini adalah data-data tentang identitas subyek dan data-data tentang variabel terikat tentang hasil menendang bola. Data tentang subyek penelitian diperoleh pada saat penentuan subjek penelitian. Nama siswa yang menjadi anggota sampel adalah terlampir pada lampiran no 1 Sedangkan sumber data-data tentang vaiabel terikat diperoleh pada saat menendang bola. Adapun data-data tersebut dipaparkan pada tabel-tabel dibawah ini: Langkah-langkah yang ditempuh dalam menganalisis data dalam penelitian ini antara lain: (a) Merumuskan Hipotesis Nol (Ho), Hipotesis yang dirumuskan atau diajukan dalam penelitian ini adalah hipotesis alternatif (kerja) yang menyatakan bahwa: Ada pengaruh gaya mengajar resiprokal terhadap hasil menendang bola pada siswa putra kelas VII SMPN 1 Gerung Lombok Barat. Untuk membuktikan apakah 
hipotesis tersebut terbukti kebenarannya , maka hipotesis kerja tersebut harus diubah dahulu menjadi hipotsis nol (Ho), sehingga hipotesisnya berbunyi :Tidak Ada pengaruh gaya mengajar resiprokal terhadap hasil menendang bola pada siswa putra kelas VII SMPN 1 Gerung Lombok Barat. (b) Membuat Tabel Kerja, Langkah berikutnya adalah membuat tabel kerja dengan data yang diperoleh seperti pada berikut ini:

Tabel Kerja tentang Pencarian Nilai t

\begin{tabular}{|c|c|c|c|c|c|c|}
\hline \multirow{2}{*}{ No } & \multirow{2}{*}{ Nama } & \multicolumn{2}{|c|}{ Nilai } & \multirow{2}{*}{ D } & \multirow{2}{*}{ d } & \multirow{2}{*}{$d^{2}$} \\
\hline & & XI & $\mathrm{X} 2$ & & & \\
\hline 1 & Aldo Ade Pratama & 66 & 58 & 8 & 1,517 & 2,301 \\
\hline 2 & Alif Arya Saputra & 66 & 58 & 8 & 1,517 & 2,301 \\
\hline 3 & Lalu Faozi Aprian Hadi & 66 & 66 & 0 & $-6,483$ & 42,029 \\
\hline 4 & Yoga Adi Putra Wardana & 58 & 50 & 8 & 1,517 & 2,301 \\
\hline 5 & Didi Saputra & 58 & 58 & 0 & $-6,483$ & 42,029 \\
\hline 6 & I Wayan Agus & 66 & 58 & 8 & 1,517 & 2,301 \\
\hline 7 & Lalu Dalil Falihin & 58 & 50 & 8 & 1,517 & 2,301 \\
\hline 8 & Lalu Wiki Wahyunadi & 58 & 50 & 8 & 1,517 & 2,301 \\
\hline 9 & Rian Hidayat & 66 & 58 & 8 & 1,517 & 2,301 \\
\hline 10 & Budiman & 58 & 58 & 0 & $-6,483$ & 42,029 \\
\hline 11 & Fathulrahman & 74 & 74 & 0 & $-6,483$ & 42,029 \\
\hline 12 & Kardiawan & 74 & 58 & 16 & 9,517 & 90,573 \\
\hline 13 & Muhammar Khadafi & 66 & 58 & 8 & 1,517 & 2,301 \\
\hline 14 & Irvan Hardi & 66 & 66 & 0 & $-6,483$ & 42,029 \\
\hline 15 & Lalu naufalilham & 66 & 66 & 0 & $-6,483$ & 42,029 \\
\hline 16 & Ogi varisman & 66 & 66 & 0 & $-6,483$ & 42,029 \\
\hline 17 & Ruslan & 66 & 58 & 8 & 1,517 & 2,301 \\
\hline 18 & Satria alwijaya isworo & 74 & 58 & 16 & 9,517 & 90,573 \\
\hline 19 & Yasid bastomi anifin & 66 & 58 & 8 & 1,517 & 2,301 \\
\hline
\end{tabular}




\begin{tabular}{|l|l|l|l|l|l|l|}
\hline $\mathbf{2 0}$ & Bagus Kumiawan & 74 & 58 & $\mathbf{1 6}$ & $\mathbf{9 , 5 1 7}$ & $\mathbf{9 0 , 5 7 3}$ \\
\hline $\mathbf{2 1}$ & Anwan Akbar Yunus & 58 & 58 & $\mathbf{0}$ & $-\mathbf{6 , 4 8 3}$ & $\mathbf{4 2 , 0 2 9}$ \\
\hline $\mathbf{2 2}$ & Hamidi R & 58 & 50 & $\mathbf{8}$ & $\mathbf{1 , 5 1 7}$ & $\mathbf{2 , 3 0 1}$ \\
\hline $\mathbf{2 3}$ & I Nyoman Tri Gunawan & 66 & 58 & $\mathbf{8}$ & $\mathbf{1 , 5 1 7}$ & $\mathbf{2 , 3 0 1}$ \\
\hline $\mathbf{2 4}$ & Satriadi & 74 & 58 & $\mathbf{1 6}$ & $\mathbf{9 , 5 1 7}$ & $\mathbf{9 0 , 5 7 3}$ \\
\hline $\mathbf{2 5}$ & Lalu Wirekarismasandi & 66 & 74 & $\mathbf{- 8}$ & $\mathbf{- 1 4 , 4 8 3}$ & $\mathbf{2 0 9 , 7 5 7}$ \\
\hline $\mathbf{2 6}$ & Hedri Bayu Wiratama & 58 & 58 & $\mathbf{0}$ & $\mathbf{- 6 , 4 8 3}$ & $\mathbf{4 2 , 0 2 9}$ \\
\hline $\mathbf{2 7}$ & Gusti Agung Krisna Candra & 74 & 66 & $\mathbf{8}$ & $\mathbf{1 , 5 1 7}$ & $\mathbf{2 , 3 0 1}$ \\
\hline $\mathbf{2 8}$ & Erdi Hariadi & 66 & 58 & $\mathbf{8}$ & $\mathbf{1 , 5 1 7}$ & $\mathbf{2 , 3 0 1}$ \\
\hline $\mathbf{2 9}$ & Miftahudin & 66 & 66 & $\mathbf{0}$ & $\mathbf{- 6 , 4 8 3}$ & $\mathbf{4 2 , 0 2 9}$ \\
\hline $\mathbf{3 0}$ & Raynaldi & 83 & 66 & $\mathbf{1 7}$ & $\mathbf{1 0 , 5 1 7}$ & $\mathbf{1 1 0 . 6 0 7}$ \\
\hline $\mathbf{3 1}$ & Vias Wahyudi Eka Putra & 66 & 50 & $\mathbf{1 6}$ & $\mathbf{9 , 5 1 7}$ & $\mathbf{9 0 , 5 7 3}$ \\
\hline JUMLAH & $\mathbf{1 9 8 1}$ & $\mathbf{1 8 4 6}$ & $\mathbf{2 0 1}$ & & $\mathbf{1 2 2 5 , 7 9 3}$ \\
\hline
\end{tabular}

$$
\operatorname{Md}=\frac{\sum D}{N}=\frac{201}{31}=6,483
$$

Keterangan :

X1 :Mean hasil menendang bola setelah menggunakan gaya mengajar resiprokal

X2 :Mean hasil menendang bola sebelum menggunakan gaya mengajar resiprokal

D :Beda antara X1 dan X2

$\mathrm{d}^{2} \quad$ kuadrat beda skor

$\mathrm{N} \quad$ : Jumlah sampel

Maka :

$$
\begin{aligned}
& M_{1}=\frac{\sum X_{1}}{N}=\frac{1981}{31}=63,903 \\
& M_{2}=\frac{\sum X_{2}}{N}=\frac{1846}{31}=59,548
\end{aligned}
$$

a. Memasukkan Data Ke Dalam Rumus 


$$
\begin{aligned}
& t=\frac{M_{1}-M_{2}}{\sqrt{\frac{\sum d^{2}}{N(N-1)}}} \\
& t=\frac{63,903-59,548}{\sqrt{\frac{1225,793}{31(31-1)}}} \\
& t=\frac{4,355}{\sqrt{\frac{1225,793}{930}}} \\
& t=\frac{4,355}{\sqrt{1,318}} \\
& t=\frac{4,355}{1,148} \\
& t=3,793
\end{aligned}
$$

Jadi nilai t hitung adalah 3,793

\section{b. Menguji Nilai T-Test}

Dari hasil perhitungan ternyata nilai t-tes yang diperoleh dari penelitian ini adalah 3,793 sedangkan nilai t-tes dalam tabel dengan taraf signifikan 5\% serta derajat kebebasan (db) $\mathrm{N}-1$ (31-1=30) adalah 1,697 kenyataan ini menunjukkan bahwa nilai t-hitung yang diperoleh dalam penelitian ini adalah lebih besar dari t-tabel.

\section{c. Menarik Kesimpulan}

Dari hasil pengujian nilai t-tes diatas, dimana t-tes adalah 3,793 lebih besar dari tabel sebesar 1,697 dengan taraf signifikan 5\% maka dapat dikemukakan bahwa hipotesis nol (Ho) ditolak dan hipotesis alternatif $(\mathrm{Ha})$ diterima. Maka kesimpulan analisis dalam penelitian ini adalah : ada pengaruh gaya mengajar resiprokal terhadap hasil menendang bola dalam permainan sepak bola pada siswa putra kelas VII SMPN 1 Gerung Lombok Barat. Sesuai dengan kenyataan bahwa rendahnya hasil belajar sepak bola yang diperoleh oleh sebagian siswa, bukan hanya disebabkan oleh kurangnya penguasaan teknik, tetapi juga disebabkan oleh gaya mengajar yang dierikan oleh guru. Dengan demikian sangat perlu adanya usaha untuk membantu siswa dalam mengatasi masalah yang dialaminya dengan maksud untuk meningkatkan hasil belajar cabang olahraga khususnya sepak bola yaitu dengan mengguanakan gaya mengajar resiprokal. Proses gaya mengajar dengan menggunakan gaya mengajar resiprokal memberikan pengaruh yang lebih baik terhadap peningkatan hasil menendang bola dalam permainan sepak bola. Hal ini disebabkan gaya mengajar resiprokal selain dalam pelaksanaannya terlebih dahulu diberikan penjelasan, para siswa juga diberikan kesempatan pada teman sebaya untuk memberikan umpan balik (feed back) atau dengan kata lain siswa dapat saling mengoreksi dan menilai satu sama lain secara langsung. Dalam gaya mengajar resiprokal tanggung jawab dalam memberikan umpan balik (feed back) bergeser dari guru keteman sebaya. Pergeseran peranan ini memungkinkan peningkatan interaksi sosial antara teman sebaya, dan bisa saling mengoreksi karena umpan balik 
langsung pada sesama siswa. Diharapkan melalui gaya mengajar resiprokal siswa dapat mencapai hasil belajar yang maksimal. Dan hasil pengujian hipotesis (analisis data) dengan menggunakan rumus t-test ternyata hipotesis alternatif $(\mathrm{Ha})$ yang diajukan dalam penelitian ini diterima sedangkan hipotesis nol (Ho) ditolak. Hasil penelitian ini berarti hasil belajar yang diajar dengan menggunakan gaya mengajar resiprokal memiliki hasil menendang bola dalam permainan sepak bola yang maksimal. Hasil ini dikarenakan hasil nilai t-test hitung dalam penelitian ini lebih besar dibandingkan dengan nilai t-tabel atau (3,793 > 1,679). Dengan demikian untuk memperoleh hasil menendang bola dalam permainan sepak bola yang maksimal maka sebaiknya menggunakan gaya mengajar resiprokal sehingga dalam penelitian ini menunjukan bahwa ada pengaruh Gaya Mengajar Resiprokal Terhadap Hasil Menendang Bola Dalam Permainan Sepak Bola Pada Siswa Putra Kelas VII SMPN 1 Gerung Lombok Barat.

\section{Simpulan}

Berdasarkan pada uraian pembahasan hasil penelitian dalam rangka untuk mencari jawaban rumusan masalah yang telah dilakukan dengan menjawab pertanyaan hipotesis yang telah dipaparkan dalam uraian pengujian hipotesis, maka hasil penelitian ini dapat disimpulkan bahwa "Gaya mengajar resiprokal mempunyai pengaruh terhadap hasil menendang bola dalam permainan sepak bola pada siswa putra kelas VII SMPN 1 Gerung Lombok Barat. Hal ini ditunjukkan dari hasil uji t-test pada taraf signifikasi $5 \%$, yang menunjukkan nilai $\mathrm{t}$ hitung $>\mathrm{t}$ tabel, yakni 3,793 >1,679.

\section{Daftar pustaka}

Arikunto, Suharsimi. 2010. Dasar-Dasar Evaluasi Pendidikan (Edisi Revisi). Jakarta: PT Bumi Aksara.

Arikunto, Suharsimi. 2006. Prosedur Penelitian Suatu Tindakan Praktek. Jakarta: Wineka Cipta. Mielke Danny. 2007. Dasar - Dasar Sepak Bola, Bandung: Pakar Raya.

Muhajir. 2007. Pendidikan Jasmani Olahraga dan Kesehatan, Bandung: Yudhistira.

Nurhasan 2001. Tes Pengukuran Dalam Pendidikan jasmani, Prinsip-prinsip dan Penerapannya, jakarta : Depdiknas.

Riyanto,Yatim. 2011. Metodologi Penelitian Pendidikan, Surabaya: SIC.

Sugiyono. 2011. Metode Penelitian Pendidikan, Bandung : Alfabeta. 